\title{
THE UNMASKED ELECTORATE: CO-PARTISANSHIP, PERSONAL EXPERIENCE, AND PERCEPTIONS OF COVID-19 RISK IN MEXICO
}

\author{
El Electorado sin Cubrebocas: Partidismo, Experiencia Personal, \\ y Percepción del Riesgo ante la COVID-19 en México \\ O Eleitorado sem Máscara: Partidarismo, Experiência Pessoal \\ e Percepções do Risco de COVID-19 no México
}

\section{REBECCA V. BELL-MARTIN @i rebecca.bell.martin@tec.mx ${ }^{1}$ ALEJANDRO DÍAZ DOMÍNGUEZ @i) alejandrod.dominguez@tec.mx ${ }^{1}$}

\author{
${ }^{1}$ Instituto Tecnológico y de Estudios Superiores de Monterrey \\ Submission: 2021-05-27 \\ Accepted: 2021-10-19 \\ First View: \\ Publication: 2021-11-08
}

Keywords:

COVID-19;

partisanship;

risk perception;

public health;

Mexico

\begin{abstract}
Research suggests partisanship influences individual perceptions of COVID-19 risk and preventative behaviors. We ask a distinct but equally urgent question: what factors are associated with variation in risk perception among copartisans? Even among members of the same party, some individuals' risk perceptions reflect the party line while others deviate from it. We explore this question in Mexico, where the president utilized his rhetoric to downplay the severity of the pandemic. Why do some of the presidents' co-partisans perceive COVID-19 as a serious risk (despite partisan appeals to the contrary), while others do not? Drawing on theories of risk perception, we hypothesize that this variation is associated with personal risk experience, like knowing someone who contracted COVID-19. We test this hypothesis via a large-n survey of MORENA supporters. We find that personal experiences are consistently associated with variation in risk perception. Strength of partisan ties, meanwhile, is only activated when paired with risk experience.
\end{abstract}




\section{Palabras clave:}

COVID-19;

partidismo; percepción de

riesgo; salud

pública; México

\section{Resumen}

Algunas investigaciones sugieren que el partidismo influye en percepciones individuales sobre riesgos ante COVID-19. Se plantea una pregunta distinta pero igualmente urgente: ¿qué factores se asocian con la variación en la percepción del riesgo entre partidarios de un mismo color? Entre integrantes del mismo partido, algunas percepciones de riesgo reflejan la línea partidista mientras que otras se desvían de ella. Se analiza México, donde el presidente utilizó su retórica para minimizar la gravedad de la pandemia. ¿Por qué algunos de los copartidarios del presidente perciben un riesgo grave mientras que otros no? Con base en teorías sobre percepción del riesgo, se plantea que esta variación puede asociarse con experiencias personales como conocer a quien contrajera COVID-19. La hipótesis se verifica mediante una encuesta entre partidarios de MORENA. Se halla que experiencias personales están asociadas con variaciones en la percepción del riesgo. Los lazos partidistas sólo se activan cuando se conectan con experiencias de riesgo.
Palavras-chave:

COVID-19; partidarismo; percepção de risco; saúde pública; México

\section{Resumo}

Pesquisas sugerem que o partidarismo influencia as percepções individuais sobre o risco de COVID-19 e comportamentos preventivos. Fazemos uma pergunta distinta, mas igualmente urgente: quais são os fatores que estão associados à variação na percepção de risco entre copartidários? Mesmo entre os membros do mesmo partido, as percepções de risco de alguns indivíduos refletem a linha do partido, enquanto outros se desviam dela. Exploramos esta questão no México, onde o presidente utilizou sua retórica para minimizar a gravidade da pandemia. Por que alguns dos co-partidários dos presidentes percebem COVID-19 como um risco sério (apesar dos apelos partidários em contrário), enquanto outros não? Com base em teorias de percepção de risco, levantamos a hipótese de que essa variação está associada à experiência de risco pessoal, como, por exemplo, conhecer alguém que contraiu COVID-19. Testamos essa hipótese por meio de uma pesquisa geral com apoiantes do MORENA. Descobrimos que as experiências pessoais estão consistentemente associadas à variação na percepção de risco. A força dos laços partidários, por sua vez, só é ativada quando entra em contato com a experiência de risco.

\section{INTRODUCTION}

Public opinion research suggests that citizen perceptions of the coronavirus (COVID-19) pandemic are influenced by partisan affiliation. Partisanship shapes an individual's perception of their risk of falling victim to COVID-19, their assessment of the overall gravity of the pandemic, and attitudes toward mitigation measures (Aruguete and Calvo, 2020; Dryhurst et al., 2020; Clements, 2020; Pickup et al., 2020; Sobral et al., 2020; Batista Pereira and Nunes, 2021; Calvo and Ventura, 2021; Clinton et al., 2021; Gadarian et al., 2021; Arugete et al., 2021). The preponderance of research on how partisan affiliation shapes COVID-19 risk perception was carried out in the global North, primarily in the United States (US). In response, a number of the aforementioned studies address the role of partisanship 
and public opinion about COVID-19 in the global South. Identifying how partisan affiliation shapes attitudes toward COVID-19 across the world represents an important scholarly contribution during an unprecedented time.

We ask a distinct but equally urgent research question: what factors are associated with variation in risk perception among co-partisans? In other words, we assume that partisan identification matters and instead investigate an unexplained source of variation, differences in risk perception among members of the same party. Among co-partisans, not everyone will share the same views about COVID-19 risk. Some will toe the party line. Others will deviate from it, apparently betraying their partisan allegiances. We are particularly interested in this relationship in contexts like the US, Mexico, and Brazil, where party elites dismissed the gravity of the virus. In contexts like these, why do some co-partisans perceive COVID-19 as a serious risk (despite partisan appeals to the contrary), while others do not?

We advance upon the aforementioned works by exploring this question in one important case: Mexico. Mexico's COVID-19 experience shares important similarities with the US, where the link between partisanship and COVID-19 attitudes is clear. Both countries' highest elected officials downplayed the gravity of the virus. Just as then-President Donald J. Trump tried to persuade Americans that the virus would vanish quickly and that most infections were "99\% harmless" (Smith, 2020), Mexico's president, Andrés Manuel López Obrador, encouraged citizens to continue frequenting businesses and ridiculed World Health Organization recommendations to stay home and wear a mask (Ahmed, 2020; Reuters, 2021). Instead, he claimed to rely on his own honesty, along with a collection of protective amulets, to defend himself (Dyer, 2020). Like Trump, López Obrador is considered a populist by many and was elected on an anti-establishment platform that deepened political polarization in the country (Moreno, 2021). López Obrador is a founding member of the Movimiento Regeneración Nacional party (hereafter MORENA). Despite López Obrador's attempts to minimize the pandemic's severity, citizens vary widely in the degree to which they consider it a serious threat, even among his supporters (Mendoza Blanco \& Asociados 2020). What explains variation among the President's allies?

Drawing on theories of risk perception, we argue that personal experience with COVID-19, such as knowing someone who was infected, helps us understand variation in COVID-19 risk perception among supporters of the same political party, or co-partisans. We argue that personal experience helps individuals recognize and accept their susceptibility to virus-related risks, and consequently, are more likely to perceive COVID-19 as a threat. We test this hypothesis via a large-n survey of MORENA-leaning voters in Mexico. We exploit individual-level variation in degree of partisan allegiance to MORENA and personal experience with COVID-19, 
thereby evaluating whether and to what degree personal experience shapes risk perceptions among strong versus weak co-partisans.

Understanding risk perception is important because perceiving one's particular risk is a precursor to self-protection behaviors preventing a range of COVID-19 related problems (Pedersen and Favero, 2020; Tyson, 2020). Our focus on variation in risk perception among co-partisans is particularly important because it lends insight into whether and how the influence of partisanship can be attenuated. By identifying possible factors that lead co-partisans to recognize COVID-19 risk despite partisan efforts to downplay it, we can generate hypotheses about how those most likely to dismiss COVID-19 threats can be similarly persuaded.

In this regard, Mexico is an especially relevant case. Of the five countries with the world's highest COVID-19 death rates - US, Brazil, Mexico, India, and the United Kingdom (UK) - three are in the global South (Pettersson et al., n.d.). Moreover, Mexico reflects an emerging context in the Americas: increasing polarization and populism. The US, Brazil, and Mexico were led by populist leaders who minimized the pandemic's severity during its first year. Now, they hold the highest COVID-19 death rates in the hemisphere. In Brazil, this increased the disease's spread and reduced social distancing compliance in pro-government localities (Ajzenman, Cavalcanti and Da Mata, 2020; Argentieri Mariani et al., 2020; Testa et al., 2021). In the US and Brazil, districts with high voter support for Trump and Bolsonaro, respectively, have steeper COVID-19 epidemiological curves (Ajzenman, Cavalcanti and Da Mata, 2020; Allcott et al., 2020; Argentieri Mariani et al., 2020). Even so, Testa et al.'s (2021) comparative analysis of Mexico, the US, and Brazil suggests that partisan ties to these presidents do not consistently predict citizen preventive behaviors. This further highlights the need for scrutiny of the relationship between partisanship and COVID-19 attitudes and behaviors.

As noted above, our sample consists exclusively of co-partisans. That is, individuals who expressed some level of sympathy with the MORENA party, though their individual degree of sympathy varies. Our focus on MORENA co-partisans has two strengths. First, we assume MORENA-leaning voters are more likely to be exposed to and persuaded by López Obrador's COVID-19 messaging relative to non-supporters (Kahan, 2015). We thus provide a hard test of the power of personal experience by focusing on those for whom partisan cues should be most salient. Second, it advances knowledge about the relationship between partisanship and risk perception by scrutinizing a heretofore unexplored source of variation, degree of partisanship among co-partisans. It is not clear whether and to what degree different levels of partisan allegiance shape COVID-19 attitudes. Do those who enthusiastically support the party perceive COVID-19 risk differently than those who only tentatively do so? By investigating this variation, which we define as strength of partisan affiliation, alongside variation in personal experiences with COVID-19, we improve on this shortcoming. 
In sum, our research advances existing knowledge about the relationship between partisanship and COVID-19 risk perception by asking an understudied question in the important context of the global South. We contribute to a growing body of scholarship addressing the social, political, and economic dynamics of COVID-19 in Mexico, including attitudes about government management of the crisis (Lazarus et al., 2020; Aruguete et al., 2021), pandemic-related food insecurity (Gaitán-Rossi et al., 2021), economic stress and domestic violence (López and Parás, 2020), risks associated with physical confinement (Mancini, 2021) and political factors that shape COVID-19 policies (Bennouna et al., 2021).

The article proceeds as follows. We first review existing research on the role partisanship and personal experience play in risk perception. We then outline our hypotheses, proposing that personal experience with COVID-19 shapes variation in perceptions among co-partisans. Next, we describe our data and methodological approach. We then report and discuss our results. We conclude by engaging the implications of our results for knowledge of risk perception and for public policy.

\section{Partisanship, Personal Experience, and Perception of Risk}

\section{Partisanship and Attitudes toward COVID-19 Risk}

In largely US-based studies, scholars document an empirical association between citizens' party affiliation and their evaluation of COVID-19-related risks. For example, identifying as a Republican or voting for Republican candidates is associated with less concern about contracting COVID-19 (Pickup et al., 2020) and less worry about experiencing financial effects of the pandemic (Tyson, 2020). Similarly, those who identify as Republican or Republican-leaning are less likely to view the pandemic as a serious crisis than non-Republicans (Gadarian et al., 2021; Tyson, 2020). This is true even for those living in areas with high rates of COVID-19 and who thus ostensibly face higher risk (Tyson, 2020; Clinton et al., 2021). Clements (2020), meanwhile, shows that Democrat-leaning Americans are more likely to follow science-based recommendations for preventative behaviors than their Republican counterparts. Studies outside the US complement these conclusions (Aruguete and Calvo, 2020; Dryhurst et al., 2020; Pickup et al., 2020; Sobral et al., 2020; Calvo and Ventura, 2021; Aruguete et al., 2021).

These findings build on political science literature highlighting the power of elite messaging in shaping public opinion (Zaller, 1992; Berinsky, 2007; Lenz, 2012). Zaller (1992) argues that, rather than representing a set of well-conceived and ordered thoughts, public opinion results from elite discourse. The acceptance or rejection of that discourse depends on how well the information reflects citizens' 
ideological leanings. Science communication research similarly suggests that individuals are more easily persuaded by information communicated by members of groups to which they ascribe (Kahan, 2015). Thus, it stands to reason that individual attitudes toward COVID-19 risks are similarly influenced by cues of co-partisan political elites. The observable implications of these theories lend credence to this idea. Green et al. (2020) show that US Republican leaders sent very different messages as regards COVID-19 than Democratic leaders while Gollwitzer et al. (2020) find that consuming the Republican-leaning Fox News media decreases adherence to preventive measures. Outside the US, scholars have analyzed how variation in framing and messaging by political leaders shapes attitudes toward the pandemic in Brazil (Sobral et al., 2020; Calvo and Ventura, 2021), Mexico (Aruguete et al., 2021), and Argentina (Aruguete and Calvo, 2020).

We do not test for elite messaging in our study. However, the idea that citizens' attitudes about the pandemic are influenced by messages from partisan elites undergirds much of the literature and our own assumptions about (i) why the risk perceptions of co-partisans are more likely to align with partisan narratives and (ii) why we would expect those views to be more prevalent among strong rather than weak co-partisans. Yet, the partisanship thesis leaves important questions unresolved. First, variation in risk perception among co-partisans remains unexplored. As Pedersen and Favero (2020) observe, categorical measurements of party identification (party supporter vs. non- supporter), do not "allow us to consider whether even greater differences emerge once one distinguishes between weak and strong partisans" (p. 809). Second, it does not adequately address instances in which attitudes and behaviors do not follow theoretical expectations. Aruguete et al. (2021), for example, do find significant partisan differences in citizen attitudes about the government's COVID-19 response. However, they find only limited evidence of partisan differences in perceptions of health and job risk and partial evidence that these differences depend on partisan cues. These contradictory results highlight the importance of our research question. Despite sharing the same partisan affiliation, some co-partisans will perceive great risk and take preventative measures, like vaccination, while others will not. How can we make sense of this variation?

\section{Personal Experience and Attitudes toward COVID-19 Risk}

We argue that, among co-partisans, personal experience with COVID-19 overpowers the strength of partisan ties. Under this logic, individuals with indirect or direct personal experience with COVID-19 are more likely to perceive the risks of the virus generally and their particular risk of being affected as serious, all else equal. By direct personal experience, we mean observing COVID-19 risk through 
one's own encounter (personal infection, death of a family member, or job loss, for example). By indirect personal experience, we mean observing COVID-19 risk through the experience of someone you know (a friend's infection, coworkers' job loss, and neighbors' losing their home to debt, for example).

There are a number of reasons to hypothesize that personal experience with COVID-19 sways risk evaluations to a greater degree than strength of partisan affiliation. Our logic rests on existing theories about the cognitive processes through which risk perceptions are generated. Risk perception refers to "the subjective assessment of the probability of a specified type of accident happening and how concerned we are with the consequences" (Sjöberg, Moen and Rundmo, 2004, 8). Risk perception is the product of individuals' ideas about (i) the general severity of a specific risk and (ii) the probability they will be harmed by it (El-Toukhy, 2015). The emphasis on subjectivity in the definition reflects two empirical observations. First, individuals vary in how they evaluate the same risk (i.e., air travel). Second, individuals often misplace risk. That is, they perceive great danger in a hazard whose probable risk is low (i.e, terrorism) yet readily accept a hazard whose probability of harm is comparatively high (i.e., smoking). This implies that risk perception is not a simple rational calculation of the probability or severity of danger. Instead, risk is filtered through a series of psychological channels and our existing social, cultural, and contextual lenses (Sjöberg, Moen and Rundmo 2004, 10).

Factors beyond "real" risk hypothesized to shape risk perception include those that vary at the societal level, like social or cultural context (Douglas and Wildavsky, 1983; Sjöberg, 1998), and at the individual level, like demographic traits, affect (Slovic and Peters 2006), ideology and worldviews (Douglas and Wildavsky, 1983), and as we suggest, personal experiences (Barnett and Breakwell, 2001). Partisanship is tied to theses about ideology and culture (see for example Sjöberg, 2000, 5-8). Since perceiving risk is dependent on knowing a risk exists, much research interrogates how and from whom individuals receive risk information, particularly from the media (see Wahlberg and Sjöberg 2000 for a review) and from one's social network (Kasperson, et al., 1988). Finally, a predominant line of risk psychology research explores how individuals process information to form risk perceptions. This line of thinking emphasizes information biases and heuristic tools that allow individuals to form a perception of personal risk with incomplete information. These frequently produce perceptions of risk that deviate from the "real" risk posed.

Overall, these theories suggest that personal experience is uniquely positioned to overcome obstacles to risk perception like partisanship. The "availability heuristic" refers to the information one uses when evaluating risk. Tversky and Kahneman (1973) posit that individuals assess the likelihood of a given risk by how easily they can think of relevant cases, including those that are frequently repeated in the media, communicated in a memorable way, or that occurred within one's social network (Lichtenstein et al., 1978). Evidence suggests personal experiences 
and cases within one's social network are particularly easy to recall. Pachur et al. (2012), for example, find that occurrences of cancer featured in the media played a "negligible" role on evaluations of cancer's death toll. Instead, "people appear to primarily rely on the number of recalled instances from their social network" (p. 320). The availability of direct and indirect personal experiences when evaluating risk is widely documented (Fischoff et al., 2012; Hertwig et al., 2005; Pachur et al., 2012).

Furthermore, Kahnemann and Tversky's (1982) "simulation heuristic" posits that individual estimates of a risk's occurrence increase with the ease of imaginability. That is, how easy it is for one to imagine their own potential suffering (Kahnemann \& Tversky, 1982; Sherman et al., 1985; Rothman \& Kiviniemi, 1999; Broemer 2004). Personal experiences - even those experienced indirectly - are well-positioned to heighten imaginability. Put simply, it is easier to imagine the consequences of COVID-19 after observing them through the suffering of a neighbor or friend. This logic stands in line with the Social Amplification of Risk Framework, which posits that personal experiences provide context-specific information about the nature of risk, which then informs risk perception in combination with external influences (like partisan cues) (Kasperson et al., 1988).

Empirical evidence documenting an association between personal experience and sensitivity to risk, perception of risk, and the adoption of preventative behaviors corroborates these theoretical processes. Browne and Hoyt (2000), for example, find that having experienced a flood is positively associated with the future probability of purchasing flood insurance. Barnett and Breakwell (2001) in particular find that personal experience with risks to which one is involuntarily subjected (as COVID-19 infection would be) holds greater association with perceptions of risk than standard correlates. Personal risk experiences are also tied to preventative behaviors (see Weinstein 1989 for a review).

Remarkably, this association is not limited to the experiences of individuals, friends and family. Receiving information about the experience of someone "like you" (sharing similar characteristics or behaviors) - including strangers or fictional personas - can generate a sense of personal identification that helps individuals imagine themselves facing similar risks (Rothman et al., 1999; De Wit et al., 2008; Dillard et al., 2010). As Sjöberg (2000) notes, "the types of risks where realistic perceptions can be expected appear to be the risks with which people have some experience, direct or indirect" (p. 1). The role of personal experience and COVID-19 risk perception specifically, however, remains unclear and understudied and the role of personal experience among co-partisans, as we examine in the present study, is yet to be explored.

In summary, the above research suggests that personal experience may provide a corrective to forces that stymie perception of COVID-19 risk, including partisan ties. We test this hypothesis among co-partisans in Mexico. Specifically, 
we aim to assess whether and to what degree personal experience is correlated with individual-level perception of COVID-19 risk compared to strength of political affiliation, among MORENA supporters. Following El-Toukhy (2015), we theorize that personal experience is associated with two elements of risk perception: (i) personal susceptibility to the risk and (ii) the severity of the risk in general. We hypothesize that among co-partisans, personal experience with COVID-19 is positively associated with greater concern about personal susceptibility and the pandemic's severity, all else equal. We further hypothesize that this positive association is greater than any association between strength of partisan affiliation and COVID-19 risk perception:

H1: Personal experience with COVID-19 is positively associated with greater concern about personal susceptibility to COVID-19 effects, all else equal.

H2: Personal experience with COVID-19 is positively associated with greater concern about the severity of the COVID-19 crisis, all else equal.

H3: Concern about personal susceptibility to COVID-19 is more strongly associated with personal experience than with strength of partisanship, all else equal.

H4: Concern about the severity of the COVID-19 crisis is more strongly associated with personal experience than with strength of partisanship, all else equal.

Additionally, we develop hypotheses for possible interaction effects between partisanship and personal experience. We draw on the logic that militants are more likely to toe the party line and expect that any effect of personal experience will be greater for sympathizers than for militants:

H5: Concern about personal susceptibility to COVID-19 is greater among sympathizers with a personal experience than militants with a personal experience, all else equal.

H6: Concern about the severity of the COVID-19 crisis is greater among sympathizers with a personal experience than militants with a personal experience, all else equal. 


\section{DATA AND METHODOLOGY}

We use nationally-representative, individual-level survey data from Mexico to test these hypotheses. ${ }^{1}$ The face-to-face surveys were carried out six months into the pandemic (September $22-28,2020$ ) on behalf of Mexico's National Electoral Institute (INE), as part of the election of party leadership mandated by the Electoral Tribunal (Díaz, 2020). Since the surveys were used to elect the leadership of only the MORENA party, anyone who did not identify themselves as sympathizing at least minimally with MORENA was excluded from completing the full survey. The sample includes both registered party members and those who are not registered but expressed some support for the party, resulting in a total of 1,602 MORENA co-partisan supporters (INE, 2020). In addition to registering whether the respondent identified with MORENA, or not, the questionnaire measured respondents' name recognition of MORENA's leadership candidates, whether they are a registered party member, and basic demographics (age, gender, and education level). Finally, interviewees were asked to share their opinions about COVID-19 risk, how many people they know who have been infected, and whether or not they have fallen into debt as a consequence of COVID-19.

Our main dependent variables are (i) perceptions about the severity of the COVID-19 crisis in general and (ii) perceptions of personal susceptibility to COVID-19 effects. To measure the first, we analyze responses to the question, "Which of the following best describes your feelings about coronavirus in Mexico?"2 Possible responses were: (1) "It is not that bad" (2) "The worst is over" or (3) "The worst is still to come." To measure the second, we analyze responses to the question, "How worried are you about being infected with the coronavirus?" ${ }^{3}$ Responses were measured on a scale of 1-5, where 1 signifies "not at all" worried and 5 signifies "very worried."

Our primary independent variables are strength of partisan affiliation and personal experience with COVID-19. To measure strength of partisan affiliation, we divide survey respondents into those who identify as a registered member of MORENA, whom we call "party militants" 4 (strong co-partisans), and those who indicate they sympathize with the party but are not registered party members,

1. The survey was conducted by Mendoza Blanco \& Asociados using a structured questionnaire drafted by INE (INE 2020). Responses were carried out in Spanish at the respondent's household and captured using a mobile device.

2. “¿Cuál de las siguientes opciones describe mejor sus sentimientos sobre el coronavirus en México?” All translations by the authors.

3. “QQué tan preocupado está usted de ser contagiado con el coronavirus?".

4. The question reads: "Are you a militant of MORENA, meaning, are you registered with the party?/ ¿Es usted militante de MORENA, es decir, se encuentra registrado en el partido?”. 
whom we call "sympathizers" (weak co-partisans). ${ }^{5}$ We compare these two groups as an indicator of strength of partisan affiliation under the assumption that party registration indicates a greater degree of allegiance to the party than merely sympathizing with (but not joining) the party.

Note that this dichotomization is a measurement strategy, not a conceptual distinction. Our argument considers variation in strength of partisan affinity among co-partisans, as measured by comparing militants to sympathizers. Ideally, we would analyze variation in these different degrees of sympathy rather than the dichotomy. While the survey included a relevant question in that regard, the data is not publicly available. ${ }^{6}$ Instead, Mendoza Blanco \& Asociados report the frequencies of these responses, which are in line with our assumption that registering with the party is an expression of the greatest degree of partisan affinity. Among those who expressed support for MORENA but did not join the party, only 8.3 percent reported the highest degree of partisan affinity. The majority of whom we call sympathizers (68.9 percent) report sympathizing only "a little" to a "regular" amount. We present these frequencies in Table A1 in the Appendix.

\section{MEASURING PARTISAN IDENTIFICATION IN MEXICO}

Campbell, et al. (1960) define party identification as, "the individual's affective orientation to an important group-object in his environment" (p. 121) and measure it as, "Generally speaking, do you think of yourself as a Republican, a Democrat, an Independent, or what?" (p. 122). This formulation is common in a two-party system and frequently joins questions about strength and attachment on a 7-point Likert scale. In our data, respondents were asked, "Do you sympathize with MORENA?" and later, "Are you a militant of MORENA, meaning, are you registered with the party?" While these depart from Campbell, et al.'s formulation, there is little consensus about standard question wording for multiparty systems like Mexico's. Questions about partisanship range from measuring closeness, to sympathy, identification, and the formulation "do you consider yourself as...?" (Castro-Cornejo, 2019; Díaz, 2020a). Our question about sympathies for MORENA is similar to other surveys carried out in Mexico (Castro Cornejo, 2019). Conceptually, party identification "can persist without legal recognition or evidence of formal membership and even without a consistent record of party support" (Campbell et al., 1960: 121), so self-report measures like ours are appropriate and valuable in contexts of

5. The question reads: "Do you sympathize with MORENA? / ¿Usted simpatiza con MORENA?".

6. Respondents indicated whether they sympathize with the party "a little," "a regular amount," "a lot," or "a great deal" ("Poco, Regular, Mucho, Muchísimo"). 
BELL-MARTIN AND DÍAZ DOMÍNGUEZ

THE UNMASKED ELECTORATE: CO-PARTISANSHIP, PERSONAL EXPERIENCE, AND PERCEPTIONS OF COVID-19 RISK IN MEXICO

emergent parties (like MORENA) and new party systems, like Mexico's (CastroCornejo, 2019).

Psychology-based notions of party identification like Campbell, et al. (1960) are challenged by rationality-based approaches, in which evaluations of the economy, among other issues, may explain the stability of party identification (Fiorina 1981). In Mexico, for example, this could explain changes in identification with MORENA in 2018, perhaps resulting from negative evaluations of the Mexico City mayor's incumbent party (the Democratic Revolution Party, or PRD) and positive evaluations of a social welfare program linked to López Obrador (Sánchez y Sánchez, 2019). We do not address this debate because our goal is not to adjudicate between competing explanations for how one becomes a sympathizer or a militant. Rather, given identification, we explore how variation in the strength of those ties correlates with COVID-19 risk perceptions.

As noted above, MORENA is an emergent party. However, it has quickly gained power and support that rival or supersede Mexico's more enduring parties, suggesting that approaches to understanding partisan identification with more established parties are also useful here. National-level identification with MORENA increased steadily between its official establishment in 2014 and 2019 (Buendía and Márquez 202), increasing from 12 to 30 percent between 2018 2019 alone (Moreno 2019). As of the 2021 midterm elections, MORENA governs 17 of Mexico's 32 states, the majority of which it wrested from the long-standing Partido Revolucionario Institucional (PRI) (Morán-Breña 2021). Prior to the 2021 elections, MORENA held both the Presidency and a congressional majority in the lower house.

Given López-Obrador's populist appeal, it is possible that what we measure is not party identification but instead populist identification with the President. Even so, we are confident that our measure captures individual affinities with the party. Most importantly, the survey questionnaire asks only about MORENA and does not mention the President. Other surveys suggest that respondents distinguish between the two. In Moreno (2019), for example, four out of ten respondents indicated feeling more aligned with MORENA than the President. Thus, we are confident that participants' responses about identification with MORENA reflect party preferences, though these likely share some overlap with affinity for the President himself.

Finally, readers will note that the distribution of our sample is unequal, with $17 \%$ identifying as militants and $83 \%$ as sympathizers. This appears to be a general trend in partisan identification data in Mexico. Consider, for example, a 2018 survey in which respondents were asked to rate whether they identified "a lot" or "a little" with several political parties (Abundis, 2018). Responses were unequally distributed for all three major parties (PRI, PAN, and MORENA). Among all potential 
BELL-MARTIN AND DÍAZ DOMÍNGUEZ

THE UNMASKED ELECTORATE: CO-PARTISANSHIP, PERSONAL EXPERIENCE,

AND PERCEPTIONS OF COVID-19 RISK IN MEXICO

party affiliations, 17 percent of respondents indicated they sympathized with MORENA "a lot" compared to 5 percent who sympathized with MORENA "a little."

\section{MEASURING COVID-19 EXPERIENCES}

We measure two dimensions of personal experience with COVID-19-related risk: (a) knowing someone who falls ill with COVID-19 and (b) COVID-induced financial strain, like that generated by job loss. To capture the first, we measure how many people the respondent knows who have contracted COVID-19, using a five-point scale wherein the highest response category is "11 or more." To measure financial strain, we utilize a dummy variable indicating whether the respondent's household has fallen into debt because of COVID-19 (1) or not (0). ${ }^{8}$

We measure financial risk because individuals may evaluate the pandemic based on experiences that go beyond illness. Economic strain is one important way households experience COVID-19 effects and even individuals who believe COVID-19 is not a dangerous illness may be concerned about the pandemic's economic consequences. Moreover, theories of risk posit that "threat in one area of life spreads and leads to increased risk perception also in other areas" (Sjöberg, 1998, p.90). Thus, there is reason to hypothesize that financial harm will exhibit an association with perceptions of other COVID-19-related risks. We expect both types of experiences - knowing someone who contracted the virus and COVID19-induced debt - will have similar associations with perceptions about the general severity of the pandemic and individual risk of falling ill. ${ }^{9}$

Finally, we also control for the available demographic variables, including gender, age, education level, whether the respondent lives in an urban versus rural space, and geographic regions of the country. Gender is measured as a binary variable (male/female). Age is measured in six cohorts with a range of eighteen to sixty-six or more years old. Education is measured as having completed either elementary, secondary, high school, college, or no formal education. Urban versus rural is a binary measure, and lastly, the documented regions include the

7. The question reads: "How many people do you know who have been or are sick with coronavirus? I ¿A cuánta gente cercana conoce que haya estado o que esté enferma de coronavirus?".

8. The question reads: "Has your household gone into debt in order to cope with the coronavirus emergency? / ¿En su hogar se han endeudado para enfrentar la contingencia por el coronavirus?".

9. Respondents may have been in poor financial straits prior to the pandemic. If debt results from something other than COVID-19, is it considered a COVID-19 experience? Since risk evaluation is a subjective process, whether or not respondents perceive debt as a COVID-19 experience is of greater theoretical importance than the actual origins of debt. The survey question (see above) captures this. We assume that affirmative responses to this question reflect respondents who believe their household has been affected by COVID-19 via financial strain. 
Northwest, Northeast, Central West, Central East, and the South. Descriptive statistics are displayed in Table A2 of the Appendix. ${ }^{10}$

We estimate the relationship between partisan strength, personal experience, and perceptions of risk employing two dependent variables. In the first, we estimate perceptions about the severity of the COVID-19 crisis in general via a multinomial logistic regression. In the second, we estimate perceptions about one's own susceptibility to COVID-19 risk via an ordered logit regression. We then estimate interactive models combining partisan strength and personal experience. We include robust standard errors and the corresponding weights indicated by the Mendoza Blanco \& Asociados survey.

\section{RESULTS AND DISCUSSION}

\section{Perceptions about the Severity of the COVID-19 Crisis}

To estimate perceptions of the pandemic's severity, we conducted a multinomial logistic regression with four possible response categories: "the worst is over," "the worst is still to come," "it is not that bad," and "I do not know," the latter being the reference category. Table A3 in the Appendix displays the results. Overall, being a militant increases the probability that a respondent will express some opinion about the gravity of the crisis, relative to responding, "I do not know." In other words, militants appear to have more well-formed opinions relative to sympathizers. However, those opinions do not follow a clear pattern as regards the pandemic's severity. There is no other substantive difference between militants and sympathizers in this estimation, suggesting that strength of partisanship does not explain the observed variation among co-partisans.

Personal experience with COVID-19 risk, in contrast, does shape attitudes about the gravity of the pandemic. Among all co-partisans, those who know someone who caught COVID-19 or are in debt due to the pandemic are more likely to express a negative outlook about the pandemic. Specifically, they are more likely to say that "the worst is still to come," and are less likely to conclude that the crisis is "not so bad," relative to those without the same experiences. Knowing someone who is sick with COVID-19 has a marked influence on these perceptions. When the number of COVID-19-diseased people in one's social circle increases from zero to eleven or more, the likelihood of perceiving the pandemic as "not that bad" decreases from 12 percent to 5 percent (see Panel C of Graph A4 in the Appendix).

10. The COVID-19 variables are somewhat related but a correlation matrix, principal component analysis and Chronbach's alpha reliability score (.03) suggest these variables capture distinct concepts (see Table A7 in the Appendix). 
Increasing the number of COVID-19 ill people one knows increases the probability of believing that "the worst is yet to come" by around 20 points. In line with theoretical expectations that personal experience increases one's risk knowledge, knowing someone ill with COVID-19 also reduces the likelihood that a MORENA co-partisan will respond "I do not know," when asked to evaluate the gravity of the pandemic. Our estimations between experiencing COVID-19-related debt and perceptions of the severity of the pandemic mirror these findings. Table A3 and Graph A4 in the Appendix show a weak association between indebtedness and more favorable outlooks of the pandemic. This stands in contrast to a highly significant $(p<.01)$ association between indebtedness and thinking that "the worst is yet to come." When we consider the strength of partisan ties, in contrast, we find that being a militant merely reduces the likelihood of not having an opinion about the pandemic's general severity by about five points (see Panel B of Graph A4 in the Appendix). Thus, the strength of partisanship is not a strong predictor of perceptions of the pandemic's severity, when compared to sympathizers.

\section{Perceptions of Personal Susceptibility to COVID-19 Effects}

We display estimates of risk perceptions of personal susceptibility to COVID-19 in the base model from Table A5 in the Appendix and Graph 1 below. We observe no significant relationship between strength of partisan affiliation among MORENA co-partisans and concern about falling victim to COVID-19. The results instead confirm our hypothesis that personal experience with COVID-19 risk is more strongly associated with individual perceptions of COVID-19 risk. This is most readily observable in the base model, where knowing someone who has been infected is positively associated with concern about one's own risk of infection, all else equal. This relationship holds when we consider financial risks. Relative to those who have not experienced COVID-induced debt, those who have are significantly more concerned about their susceptibility to infection, all else equal. This latter finding suggests that the various experiences one might have with COVID-19 are interrelated. For example, the possibility of infection (and the resulting economic shortfalls due to illness) may loom particularly large in the minds of those who are already in debt.

Finally, we ran an additional model interacting personal experiences with COVID-19 illness and debt with strength of partisan affiliation to estimate their joint association with (i) perceptions about general COVID-19 severity and (ii) perceptions of one's own risk of contracting COVID-19. Regarding the first, doing so did not reveal any statistically significant relationship between being a militant co-partisan and knowing someone who is sick, nor being a militant and going into 


\section{Graph 1. Predicted Probabilities of Worried about Contagion}

A

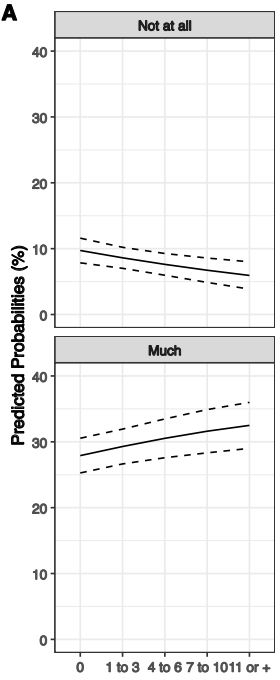

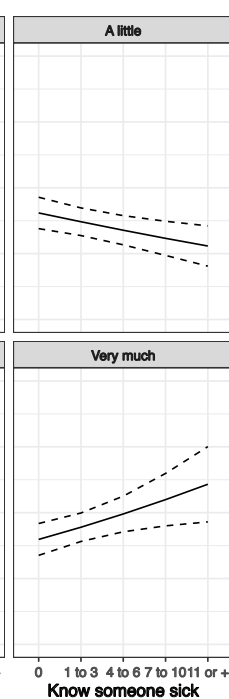

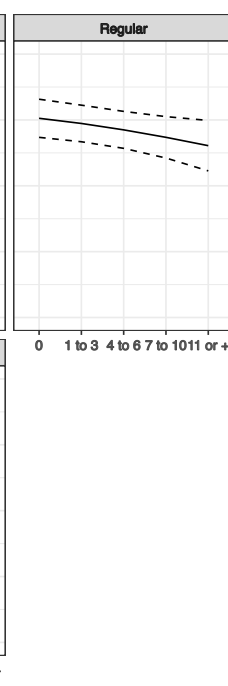

B

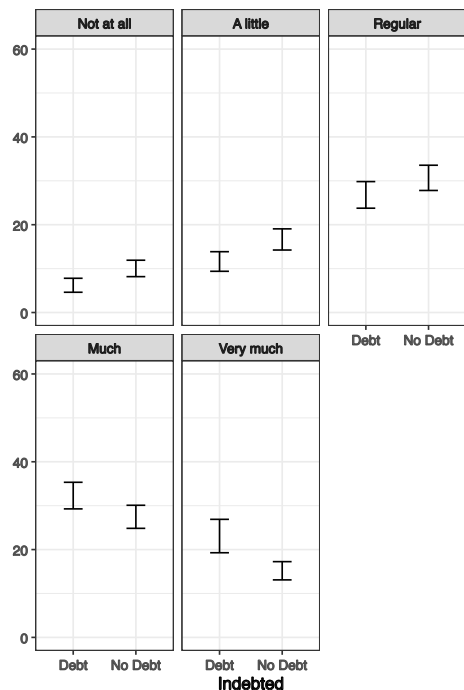

Source: Base Model from Table A5. Panel A: effects of knowing someone sick. Panel B: effects of being indebted.

Notes: Survey conducted by Mendoza Blanco \& Asociados. Methodology: multistage stratified sample of 1,602 Mexican citizens - 18 years old and more- self-reported militants and/or sympathizers of MORENA, a national representative sample, conducted in households, administered face-to-face from September 22 to 28 of 2020, rejection rate $40.5 \%$.

debt because of the pandemic. ${ }^{11}$ However, we do find a significant relationship between perceptions about one's personal risk of catching COVID-19 and the interaction term between knowing someone who is sick and being a militant. This relationship only holds for the unique experience of knowing someone who has caught COVID-19. We do not find this same relationship for having experienced pandemic-related debt. Results are shown in the interactive model from Table A5 in the Appendix.

11. Why do we only observe the interactive association with perceptions of personal susceptibility to infection and not the pandemic's severity? One possibility is that the particular interactive association is sensitive to differences in the specificity of the question. Evaluations of the severity of the pandemic are categorized into three broad categories and we do not know what precise social, political, or economic information citizens draw on to form those perceptions. Level of worry about contagion, in contrast, is measured in finer detail (1-5 scale) and respondents evaluate just one potential risk - infection - rather than the whole of the pandemic. We hope to explore this puzzle in future research. 
To know the specific impact of the significant interaction term on perceptions of COVID-19 risk, we show predicted probabilities in Graph 2 below. Due to the ordinal nature of the dependent variable, we present five panels that correspond to the response categories associated with the dependent variable question, "How worried are you about contracting COVID-19?" Possible responses range from "not at all" to "very much." For the responses "not at all," "a little," and, "much," there are no statistical differences, as indicated by overlapping confidence intervals. For the responses "regular" and "very much," we observe significant differences among those who know eleven or more people who contracted COVID-19. In the former, being a militant who knows eleven or more COVID-infected people increases the likelihood of reporting a "regular" level of concern about their own susceptibility to the illness. In the latter, being a sympathizer who knows eleven or more infected people increases the likelihood of reporting that one is "very much" concerned about their own risk. Among all co-partisans who know eleven or more COVID-infected people, militants have a 13 percent probability of indicating they are "very much" worried about their own COVID-19 risk, whereas sympathizers' likelihood of reporting the same level of concern is more than double that of militants (29 percent). This represents a sixteen-point difference in the probability of reporting the same level of risk perception.

Critically, these results suggest that strength of partisanship only matters when considered in conjunction with personal experience. Strength of partisan commitment to MORENA has no effect on concerns about falling ill to COVID-19 on its own (see base model from Table A5). The effect is limited, but relevant. The three constitutive terms are significant, but the interaction is negative, indicating that the effect is not valid for the full range of possible responses. Instead, we only observe this effect for responses indicating that the individual feels a "regular" amount of concern or is "very much" concerned about contracting COVID-19.

This is an intriguing finding that, to our knowledge, has not been addressed elsewhere. Recall that we argue personal experiences matter for risk perception more so than strength of partisan affinities. Our two non-interactive analyses support these hypotheses. This third, interactive model corroborates those findings. What is more, these results suggest that strength of partisan affiliation only matters amidst a preponderance of personal experience (that is, knowing 11+ COVIDinfected people). Once partisan ties enter into the relationship at this heightened level of personal experience, the levels of worry we observe ("Regular" for militants and "Very Much" for sympathizers) reflect what existing literature would expect for those groups: party militants are more likely to align themselves with the MORENA narrative that COVID-19 is not serious (and thus worry less). Sympathizers, meanwhile, are less likely to align themselves so tightly with MORENA COVID-19 narratives and thus exhibit greater concern. Why strength of partisan affiliation enters into the association only at these extreme levels of personal 


\section{Graph 2. Predicted Probabilities of Worried about Contagion (Interaction)}
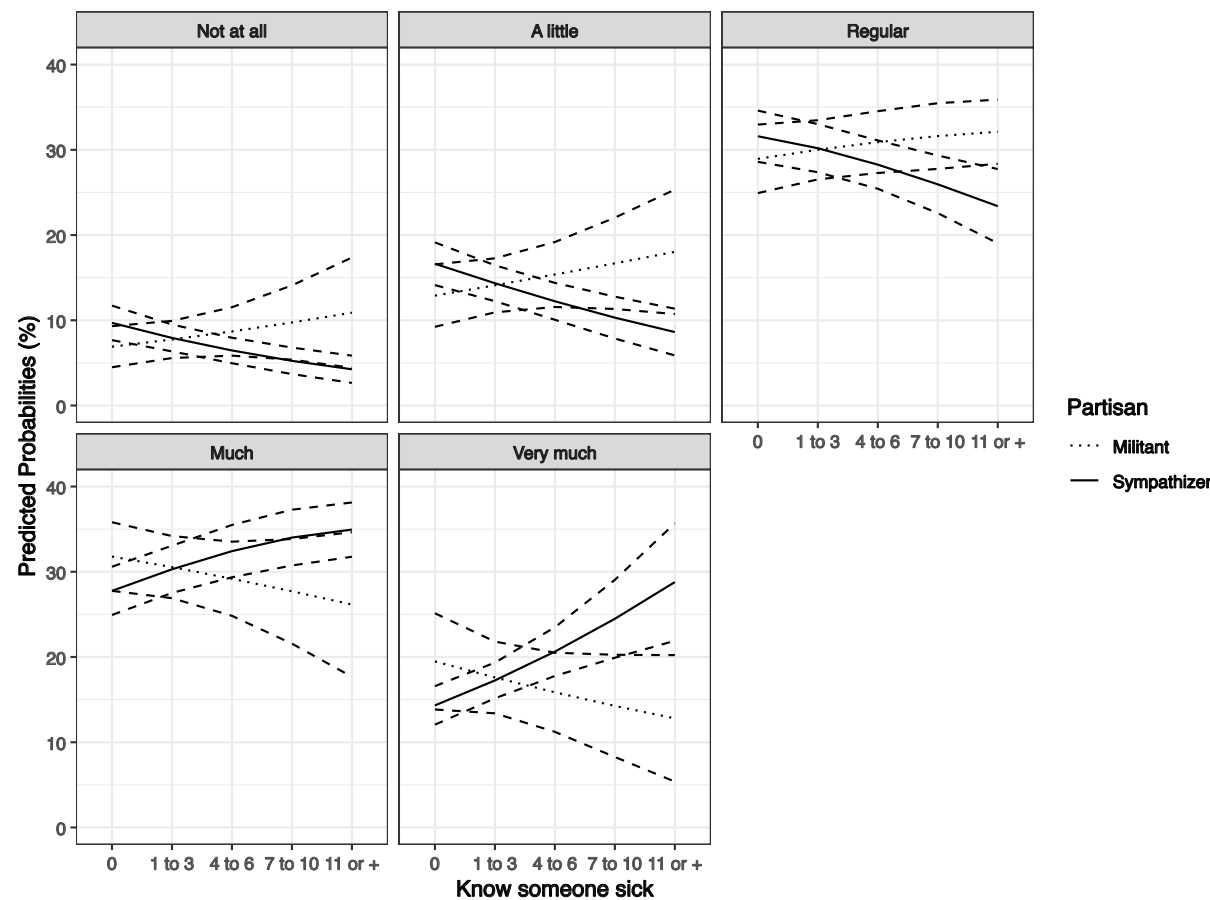

Source: Interactive Model from Table A5 (see online appendix). Effects of knowing someone sick and type of partisanship on categories of worried about contagion.

Notes: Survey conducted by Mendoza Blanco \& Asociados. Methodology: multistage stratified sample of 1,602 Mexican citizens -18 years old and more-, self-reported militants and/or sympathizers of MORENA, a national representative sample, conducted in households, administered face-to-face from September 22 to 28 of 2020, rejection rate $40.5 \%$.

experience remains unclear. Our data do not allow us to test additional hypotheses related to this question, but we believe this is a novel and important finding that merits future research.

Our knowledge would also benefit from exploring the association between financial strain and COVID-19 risk perceptions further. Our analysis suggests that, when considered alone, there is a significant association between COVID-induced debt experience and risk perceptions. We do not observe this same correlation when considering debt experiences jointly with strength of partisan identification. Why? The survey data we use does not include the income measures required to 
BELL-MARTIN AND DÍAZ DOMÍNGUEZ

THE UNMASKED ELECTORATE: CO-PARTISANSHIP, PERSONAL EXPERIENCE, AND PERCEPTIONS OF COVID-19 RISK IN MEXICO

fully understand this association, like income, health expenditures, savings, and job loss. Future research would also benefit from a Structural Equations Model (SEM) that can adequately capture the multidimensional aspects of financial wellbeing.

\section{Demographics and Other Correlates}

While exploring the association between strength of partisan affiliation, personal experiences with COVID-19 risk, and risk perceptions among co-partisans was our primary aim, the models reveal a number of demographic factors associated with risk perceptions among MORENA allies, including gender, education levels, and regions, all of which are in line with existing research and which suggest alternative correlates of risk perception identified by the psychology literature are not driving our results. We discuss these demographic findings in A8 of the Appendix. We are likewise confident that factors beyond demographics do not motivate our findings. Cultural context, for example, is unlikely to correlate given that the analysis was carried out in a single country. Given the overlap between ideological leanings and political preferences, many psychology accounts tie ideology to partisanship, which we account for. Our analysis does not allow us to explore affect as an alternative explanation. However, affect does not emerge spontaneously. Even if affect were at play in our analysis, our evidence suggests that any affective mechanism is generated by personal experiences.

Apart from the interactive effect of strength of partisan affiliation and knowing eleven or more COVID-infected people (as reported in Graph 2), our analysis did not reveal any statistically significant relationship between strength of partisan affiliation and risk perception among co-partisans. We argue this is due to the superior persuasiveness of personal experience relative to strength of partisan ties. An alternative interpretation of the absence of partisan effects is that there is no real conceptual difference between the strong partisans ("militants") and weak partisans ("sympathizers") in our sample. Indeed, the survey researchers indicated that some interviewees did not understand the question about party membership (Mendoza Blanco \& Asociados, 2020, p. 35). However, we find other significant differences between the responses of militants and sympathizers that suggest there is a meaningful conceptual difference. Most notably, we find that militants have more solidified opinions about COVID-19 relative to sympathizers (Table A3). This is in line with theories about how the most committed partisans should behave relative to Independents in Mexico (Castro Cornejo, 2021). Recall also that the relative frequency of different degrees of partisan affiliation follows what we would expect if party membership were an indicator of the greatest degree of partisan allegiance (Table A1 in the Appendix). As stated before, we find few 
BELL-MARTIN AND DÍAZ DOMÍNGUEZ

THE UNMASKED ELECTORATE: CO-PARTISANSHIP, PERSONAL EXPERIENCE,

AND PERCEPTIONS OF COVID-19 RISK IN MEXICO

in our sample who report the greatest degree of partisan sympathy but have not registered with the party. ${ }^{12}$

\section{CONCLUSION}

The COVID-19 pandemic is in its second year and COVID-19 remains a serious threat. Several world leaders continue to dismiss and even contest risk-minimizing behaviors and policies, particularly in populist-leaning contexts. It is crucial that we understand how to promote individual, voluntary adoption of self-protective behaviors in such contexts where, like Mexico, government leadership neither mandates nor advocates for them. Perception of risk is a necessary precondition to individual adoption of risk-minimizing behaviors, such as wearing a mask and physical isolation (Howard et al., 2021). Considering the abundant research demonstrating the importance of partisanship in shaping risk perception, any policy response should consider how political beliefs affect perceived risks and interact with policy implementation (Ajzenman, Cavalcanti and Da Mata, 2020; Allcott et al., 2020; Argentieri Mariani et al., 2020; Barrios and Hochber, 2020; Gadarian et al., 2020). Revealing the channels through which COVID-19 risks are conveyed despite dismissive or unclear partisan messaging is thus of special importance.

Existing scholarship linking partisanship to public opinion regarding COVID-19 does not provide an adequate answer. In particular, it gives little indication as to how and why individuals reject partisan appeals diminishing COVID-19 risk or the contexts under which elite messaging otherwise fails to persuade citizens. To that same point, the particular puzzle of variation in risk perception among copartisans remains unexplored. Do those with stronger partisan ties remain more committed to or persuaded by the party line than others? Our research contributes to closing this gap. The evidence we present suggests that personal experience is an important channel through which perceptions of COVID-19 risks are

12. Even if there were no conceptual differences between militants and sympathizers in our data, it merits noting that MORENA supporters in general (that is, militants and sympathizers) do not appear to toe the party line as regards COVID-19 in the way evidence from other cases suggests. Results of three different nationally-representative surveys of MORENA supporters commissioned by INE show that a large proportion of MORENA allies are worried about their own COVID-19 risk and share a negative outlook about the pandemic, despite López Obrador's appeals to the contrary. MORENA supporters expressed that "the worst is yet to come" at a rate of 44.7 percent in the Mendoza Blanco \& Asociados survey, 45 percent in the Demotecnia survey, and 37 percent in the Parametría survey. Regarding their personal susceptibility to COVID-19, respondents reported they were "moderately worried" to "extremely worried" at rates of 44.8 percent (Mendoza, Blanco y Asociados), 57 percent (Demotecnia), and 56 percent (Parametría). The evidence presented in this article suggests that personal experience with COVID-19 risk may help to clarify these otherwise puzzling outcomes. 
conveyed among co-partisans. Compared to personal experience with COVID-19, the strength of one's partisan affiliation is relatively muted, except when paired with a preponderance of personal experience. Identifying why partisan ties are activated only at the most extreme levels of personal experience is an unresolved research puzzle that deserves future inquiry.

In fact, our findings raise several questions for future research. First, in a comparative perspective, does personal experience with COVID-19 play a similar role in shaping risk perception among co-partisans elsewhere? Comparative analysis of the Mexican, Brazilian, and US contexts would be particularly fruitful given that presidential leadership in all three cases utilized partisan appeals to downplay the virus with devastating consequences (Ajzenman, Cavalcanti and Da Mata, 2020; Allcott et al, 2020; Argentieri Mariania et al., 2020). Similarly, comparative analyses could explore the relative power of personal experience and strength of partisan affiliation among different subsets of the population who may be more or less vulnerable to the physical or economic consequences of COVID-19. Especially in the global South, where marginalized populations may live in extreme precarity, the threat of COVID-19 may loom particularly large relative to partisan commitment. Another promising line of research would explore the role of political polarization, given that as polarization increases, distinctive partisan responses may align with changes in perceptions of risks (lyengar and Westwood, 2015; Green et al., 2020). Finally, scholars should explore how personal experience with other public health crises shape perceptions of risk. In 2009, for example, the H1N1 virus paralyzed Mexico for around four weeks as public events were cancelled and citizens were encouraged to take some of the same preventative measures recommended for the current pandemic. To what degree do these prior personal experiences shape current perceptions of COVID-19 risk?

These findings also produce important policy implications. Cognitive mechanisms that motivate risk perception through personal experience can be stimulated indirectly through hearing or reading about the experiences of someone "like you". One promising policy prescription from our research is thus to design public health campaigns that feature the personal stories of average citizens' COVID-19 experiences. De Wit et al.'s (2008) research on Hepatitis-B prevention suggests that even fictional accounts of risk experience are more effective at stimulating a personal sense of risk than two of the most common tactics currently seen in public fora - highlighting death and infection rates or merely telling the public they are at risk. Moving away from attempts to shock citizens into compliance with staggering (albeit factual) infection rates and toward instead highlighting the lived experience of fellow citizens would be a striking but impactful departure in COVID-19 preventative campaigns. 
BELL-MARTIN AND DÍAZ DOMÍNGUEZ

THE UNMASKED ELECTORATE: CO-PARTISANSHIP, PERSONAL EXPERIENCE, AND PERCEPTIONS OF COVID-19 RISK IN MEXICO

\section{REFERENCES}

Abundis, F. (2018, April 30). PAN y MORENA son los partidos con los que más se identifican los mexicanos. Carta paramétrica. http://www.parametria.com.mx/estudios/ pan-y-MORENA-los-partidos-con-los-que-mas-se-identifican-los-mexicanos/

Ahmed, A. (2020, June 8). Mexico's leftist leader rejects big spending to ease virus' sting. New York Times. https://www.nytimes.com/2020/06/08/world/americas/mexicoAMLO-economy-coronavirus.html

Ajzenman, N., Cavalcanti, T., \& Da Mata, D. (2020). More than words: Leaders' speech and risky behavior during a pandemic. SSRN. http://dx.doi.org/10.2139/ssrn.3582908

Alcott, H., Boxell, L., Conway, J., Gentzkow, M., Thaler, M., \& Yang, David. (2020). Polarization and public health: Partisan differences in social distancing during the coronavirus pandemic. Journal of Public Economics, 191, Article 104254. https://doi.org/10.1016/j. jpubeco.2020.104254

Argentieri Mariani, L., Gagete-Miranda, J., \& Rettl, Paula. (2020). Words can hurt: How political communication can change the pace of an epidemic. Covid Economics, 12, 104 $-137$.

Aruguete, N., Calvo, E., Cantú, F., Ley, S., Scartascini, C., \& Ventura, T. (2021). Partisan cues and perceived risks: The effect of partisan social media frames during the Covid-19 crisis in Mexico. Journal of Elections, Public Opinion, and Parties, 31(1), 82 - 95. https:// doi.org/10.1080/17457289.2021.1924740

Aruguete, N., \& Calvo, E. (2020). Coronavirus en Argentina: Polarización partidaria, encuadres mediáticos y temor al riesgo. Revista Sociedad Argentina Análisis Político, 14(2): 281-310. https://doi.org/10.46468/rsaap.14.2.A2

Barnett, J., \& Breakwell, G. M. (2001). Risk perception and experience: Hazard personality profiles and individual differences. Risk Analysis, 21(1), 171-178. https://doi. org/10.1111/0272-4332.211099

Batista Pereira, Frederico, and Felipe Nunes. 2021. Media Choice and the Polarization of Public Opinion About Covid-19 in Brazil. Revista Latinoamericana de Opinión Pública, February, 1-19. https://doi.org/10.14201/rlop.23681

Bennouna, C., Giraudy, A., Moncada, E., Rios, E., Snyder, R., \& Testa, P. (2021). Pandemic policymaking in presidential federations: Explaining subnational responses to COVID-19 in Brazil, Mexico, and the United States. Publius: The Journal of Federalism, 51(4), 570-600. https://doi.org/10.1093/publius/pjab025

Berinsky, A. J. (2007). Assuming the costs of war: Events, elites, and American public support for military conflict. The Journal of Politics 69(4), 975-997. https://doi. org/10.1111/j.1468-2508.2007.00602.x

Broemer, P. (2004). Ease of imagination moderates reactions to differently framed health messages. European Journal of Social Psychology, 34, 103 - 119. https://doi.org/10.1002/ ejsp.185

Browne, M. J., \& Hoyt, R. E., (2000). The demand for flood insurance: Empirical evidence. Journal of Risk and Uncertainty, 20(3), 291 - 306. https://doi.org/10.1023/A:1007823631497

Buendía, J. (1996). Economic Reform, Public Opinion, and Presidential Approval in Mexico, 1988-1993. Comparative Political Studies 29(5), 566-591. https://doi.org/10.1177/0010 414096029005004. 
BELL-MARTIN AND DÍAZ DOMÍNGUEZ

THE UNMASKED ELECTORATE: CO-PARTISANSHIP, PERSONAL EXPERIENCE, AND PERCEPTIONS OF COVID-19 RISK IN MEXICO

Buendía, J., \& Márquez, J. (2021, Feb. 23). Encuesta nacional de identificación partidista. El Universal. https://www.eluniversal.com.mx/interactivos/2021/encuesta-partidos-feb/

Calvo, E., \& Ventura, T. (2021). Will I get COVID-19? Partisanship, social media frames, and perceptions of health risk in Brazil. Latin American Politics and Society, 63(1), 1-26. https//doi.org/10.1017/lap.2020.30

Campbell, A., Converse, P. E., Miller, W. E., \& Stokes, D. E. (1960). The American Voter. New York: Wiley.

Castro Cornejo, R. (2019) Partisanship and Question-Wording Effects: Experimental Evidence from Latin America, Public Opinion Quarterly, 83(1), 26-45. https://doi. org/10.1093/poq/nfzO06

Castro Cornejo, R. (2021). How do campaigns matter? Independents, political information, and the enlightening role of campaigns in Mexico. International Journal of Public Opinion Research, Article edaa029. https://doi.org/10.1093/ijpor/edaa029

Clements, J. M. (2020). Knowledge and behaviors toward COVID-19 among US residents during the early days of the pandemic: Cross-sectional online questionnaire. JMIR Public Health and Surveillance, 6(2), Article e19161. https://doi.org/10.2196/19161

Clinton J., Cohen J., Lapinski J., \& Trussler, M. (2021). Partisan pandemic: How partisanship and public health concerns affect individuals' social mobility during COVID-19. Science Advances, 7(2), Article eabd7204. https://doi.org/10.1126/sciadv.abd7204

De Wit, J. B. F., Das, E., \& Vet, R. (2008). What works best: Objective statistics or a personal testimonial? An assessment of the persuasive effects of different types of message evidence on risk perception. Health Psychology, 27(1), 110-115. https://doi. org/10.1037/0278-6133.27.1.110

Díaz, A. (2020a). Religious Basis of Party Identification in Latin America: Denominations and Dimensions. International Journal of Latin American Religions 4, 1-13. https://doi. org/10.1007/s41603-020-00096-1

Díaz, A. (2020, October 16). Encuestas y presidencias... de partido: entre lo técnico y lo político. Nexos. https://datos.nexos.com.mx/encuestas-y-presidenciasde-partido-entre-lo-tecnico-y-lo-politico/

Dillard, A. J., Fagerlin, A., Dal Cin, S., Zikmund-Fisher, B. J., \& Ubel, P. A. (2010). Narratives that address affective forecasting errors reduce perceived barriers to colorectal cancer screening. Social Science \& Medicine, 71(1), 45-52. https://doi.org/10.1016/j. socscimed.2010.02.038

Douglas, M. \& Wildavsky, A. (1983). Risk and Culture: An Essay on the Selection of Technological and Environmental Dangers. Berkeley: University of California Press. https:// doi.org/10.1525/9780520907393

Dryhurst, S., Schneider, C. R., Kerr, J., Freeman, A. L. J., Recchia, G., van der Bles, A. M., Spiegelhalter, D., \& van der Linden, S. (2020). Risk perceptions of COVID-19 around the world. Journal of Risk Research, 23(7-8), 994-1006. https://doi.org/10.1080/13669877. 2020.1758193

Dyer, E. (2020, March 29). Mexico's choice: Amulets or science to fight COVID-19. CBC News. https://www.cbc.ca/news/politics/mexico-s-choice-amulets-or-science-to-fightcovid-19-1.5513973 
BELL-MARTIN AND DÍAZ DOMÍNGUEZ

THE UNMASKED ELECTORATE: CO-PARTISANSHIP, PERSONAL EXPERIENCE, AND PERCEPTIONS OF COVID-19 RISK IN MEXICO

El-Toukhy, S. (2015). Parsing susceptibility and severity dimensions of health risk perceptions. Journal of Health Communication, 20(5): 499-511. https://doi.org/10.1080/1081 0730.2014 .989342

Fischhoff, B., Gonzalez, R. M., Lerner, J. S., \& Small, D. A. (2005). Evolving judgments of terror risks: Foresight, hindsight, and emotion. Journal of Experimental Psychology: Applied, 11(2), 124-139. https://doi.org/10.1037/1076-898X.11.2.124

Gadarian, S. K., Goodman, S. W., \& Pepinsky, T. B. (2021). Partisanship, health behavior, and policy attitudes in the early stages of the COVID-19 pandemic. PLoS ONE, 16(4), Article e0249596. https://doi.org/10.1371/journal.pone.0249596

Gaitán-Rossi, P., Vilar-Compte, M., Teruel, G., \& Pérez-Escamilla, R. (2021). Food insecurity measurement and prevalence estimates during the COVID-19 pandemic in a repeated cross-sectional survey in Mexico. Public Health Nutrition, 24(3), 412-421. https://doi. org/10.1017/S1368980020004000

Gollwitzer, A., Martel, C., Brady, W. J., P?rnamets, P., Freedman, I.G., Knowles, E.D., \& Van Bavel, J.J. (2020). Partisan differences in physical distancing are linked to health outcomes during the COVID-19 pandemic. Nature Human Behavior, 4, 1186-1197. https://doi.org/10.1038/s41562-020-00977-7

Green, J., Edgerton, J., Naftel, D., Shoub, K., \& Cranmer, S. (2020). Elusive consensus: Polarization in elite communication on the COVID-19 pandemic. Science Advances, 6(28), Article eabc2717. https://doi.org/10.1126/sciadv.abc2717

Hertwig, R., Pachur, T., \& Kurzenhäuser, S. (2005). Judgments of risk frequencies: Tests of possible cognitive mechanisms. Journal of Experimental Psychology: Learning, Memory, and Cognition, 31(4), 621-642. https://doi.org/10.1037/0278-7393.31.4.621

Howard, J., Huang, A., Li, Z., Tufekci, Z., Zdimal, V., van der Westhuizen, H. M., von Delft, A., Price, A., Fridman, L., Tang, L., Tang, V., Watson, G.L., Bax, C.E., Shaikh, R., Questier, F., Hernandez, D., Chu, L. F., Ramirez, C. M., \& Rimoin, A. W. (2021). An evidence review of face masks against COVID-19. Proceedings of the National Academy of Sciences, 118(4), Article e2014564118. https://doi.org/10.1073/pnas.2014564118

Instituto Nacional Electoral (INE). (2020). Reporte: Encuestas de reconocimiento para proceso de elección de presidencia y secretaria general de MORENA. Retrieved October 22, 2020 from https://www.ine.mx/actores-politicos/partidos-politicos-nacionales/ encuesta-abierta-eleccion-MORENA/

lyengar, S., \& Westwood, S. (2015). Fear and loathing across party lines: New evidence on group polarization. American Journal of Political Science, 59(3), 690-707. https://doi. org/10.1111/ajps.12152

Kahan, D.M. (2015). What is the "science of science communication"? Journal of Science Communication, 14(3), 1-12. https://doi.org/10.22323/2.14030404

Kahneman, D., \& Tversky, A. (1982). The simulation heuristic. In D. Kahneman, P. Slovic, \& A. Tversky (Eds.), Judgment under uncertainty: Heuristics and biases. 201-208. Cambridge University Press. https://doi.org/10.1017/CBO9780511809477.015

Kasperson, R. E., Renn, O., Slovic, P., Brown, H., Emel, J., Goble, R., Kasperson, J., \& Ratick, S. (1988). Social amplification of risk: A conceptual framework. Risk Analysis, 8(2), 177187. https://doi.org/10.1111/j.1539-6924.1988.tb01168.x

Lazarus, J. V., Ratzan, S., Palayew, A., Billari, F. C., Binagwaho, A., \& Kimball, S. (2020). COVID-SCORE: A global survey to assess public perceptions of government responses 
BELL-MARTIN AND DÍAZ DOMÍNGUEZ

THE UNMASKED ELECTORATE: CO-PARTISANSHIP, PERSONAL EXPERIENCE,

AND PERCEPTIONS OF COVID-19 RISK IN MEXICO

to COVID-19 (COVID-SCORE-10). PLoS ONE, 15(10), Article e0240011. https://doi. org/10.1371/journal.pone.0240011

Lenz, G. (2012). Follow the leader? How voters respond to politicians' policies and performance. University of Chicago Press.

Lichtenstein, S., Slovic, P., Fischhoff, B., Layman, M., \& Combs, B. (1978). Judged frequency of lethal events. Journal of Experimental Psychology: Human Learning and Memory, 4(6), 551-578. https://doi.org/10.1037/0278-7393.4.6.551

López, C., \& Parás, P. (2020, July 27). Carencias y violencia en los hogares mexicanos durante el COVID-19. Este País. https://estepais.com/tendencias_y_opiniones/ carencias-y-violencia-en-los-hogares-covid-19/

Mancini, F. (2021). Confinement risks and social inequality in Latin America: Evidence from Argentina. Current Sociology, 1-21. https://doi.org/10.1177/0011392121990018

Mendoza Blanco \& Asociados. (2020). Encuesta de Reconocimiento. https://www.ine.mx/ wp-content/uploads/2020/10/deppp-MORENA-reporte-MendozaBlanco-EncuestaReconocimiento.pdf

Ministry of Health. (2020). COVID-19 [Data set]. Datos Abiertos. Dirección General de Epidemiología. https://www.gob.mx/salud/documentos/datos-abiertos-152127

Morán-Breña, C. (2021, June 7). MORENA ocupa el espacio que el PRI conservó en los Estados por décadas. El País. https://elpais.com/mexico/elecciones-mexicanas/2021-06-08/MORENA-arrebata-al-pri-el-poder-territorial-que-conservaba-enalgunos-estados-por-decadas.html

Moreno, A. (2019, April 26). El futuro de MORENA. El Financiero. https://www.elfinanciero.com.mx/opinion/alejandro-moreno/el-futuro-de-MORENA/

Moreno, A. (2020, April 24). La percepción de amenaza. El Financiero. https://www.elfinanciero.com.mx/opinion/alejandro-moreno/la-percepcion-de-amenaza

Moreno, A. (2021a, March 5). Se acentúa la polarización, y lo que falta... El Financiero. https:// www.elfinanciero.com.mx/opinion/alejandro-moreno/se-acentua-la-polarizaciony-lo-que-falta/

Moreno, A. (2021b, April 30). Morenistas y obradoristas. El Financiero. https://www.elfinanciero.com.mx/opinion/alejandro-moreno/2021/04/30/morenistas-y-obradoristas/

Pedersen, M. J., \& Favero, N. (2020). Social distancing during the COVID-19 pandemic: Who are the present and future noncompliers? Public Administration Review, 80(5), 805 -814. https://doi.org/10.1111/puar.13240

Pachur, T., Hertwig, R., \& Steinmann, F. (2012). How do people judge risks: Availability heuristic, affect heuristic, or both? Journal of Experimental Psychology: Applied, 18(3), 314-330. https://doi.org/10.1037/a0028279

Pettersson, H., Manley, B., \& Hernandez, S. (n.d.). Tracking Covid-19's global spread. CNN. Retrieved April 8, 2021, from https://edition.cnn.com/interactive/2020/health/ coronavirus-maps-and-cases/

Pickup, M., Stecula, D., \& van der Linden, C. (2020). Novel coronavirus, old partisanship: COVID-19 attitudes and behaviours in the United States and Canada. Canadian Journal of Political Science, 53, 357-364. https://doi.org/10.1017/S0008423920000463

Reuters. (2021, February 8). 'No, no.': Mexican president rejects mask-wearing after COVID-19 recovery. https://www.reuters.com/article/us-health-coronavirus-mexico-presidentidUSKBN2A822W 
BELL-MARTIN AND DÍAZ DOMÍNGUEZ

THE UNMASKED ELECTORATE: CO-PARTISANSHIP, PERSONAL EXPERIENCE, AND PERCEPTIONS OF COVID-19 RISK IN MEXICO

Rothman, A. J., Kelly, K. M., Weinstein, N. D., \& O'Leary, A. (1999). Promoting interest in HIV-antibody testing among heterosexually active young adults. Journal of Applied Social Psychology, 29(3), 531 - 551. https://doi.org/10.1111/j.1559-1816.1999.tb01400.x

Rothman, A. J., \& Kiviniemi, M. T. (1999). Treating people with information: An analysis and review of approaches to communicating health risk information. JNCI Monographs, 25, 44-51. https://doi.org/10.1093/oxfordjournals.jncimonographs.a024207

Sánchez y Sánchez, C. L. (2019). La identidad partidista en la Ciudad de México. EI PRD y MORENA el 1 de julio de 2018. Revista Mexicana de Opinión Pública, 26, 99-115. https://doi.org/10.22201/fcpys.24484911e.2019.26.66385

Sjöberg, L. (1998). Worry and risk perception. Risk Analysis, 18(1), 85-93. https://doi. org/10.1111/j.1539-6924.1998.tb00918.x

Sjöberg, L. (2000). Factors in risk perception. Risk Analysis, 20(1), 1-12. https://doi. org/10.1111/0272-4332.00001

Sjöberg, L., Moen, B. E., \& Rundmo, T. (2004). Explaining risk perception: An evaluation of the psychometric paradigm in risk perception research, Rotunde 84, 1-33.

Sherman S. J., Cialdini, R. B., Schwartzman, D. F., \& Reynolds, K. D. (1985). Imagining can heighten or lower the perceived likelihood of contracting a disease: The mediating effect of ease of imagery. Personality and Social Psychology Bulletin, 11(1), 118-127. https://doi.org/10.1177/0146167285111011

Smith, D. (2020, July 5). Trump claims $99 \%$ of US Covid-19 cases are 'totally harmless' as infections surge. The Guardian. https://www.theguardian.com/world/2020/jul/05/ trump-claims-99-of-us-covid-19-cases-are-totally-harmless-as-infections-surge

Sobral, F., Carvalho, J., Lagowska, U., Magalhães, L., Pimentel Furtado, G., \& Grobman, M. (2020). Better safe than sorry: Leadership sensemaking in the time of COVID-19. Revista de Administração Pública, 54(4), 758-781. https://dx.doi. org/10.1590/0034-761220200262x

Testa, P., Snyder, R., Rios, E., Moncada, E., Giraudy, A., \& Bennouna, C. (2021). Who stays home? The politics of social distancing in Brazil, Mexico, and the United States. Journal of Health Politics, Policy, and Law, Article 9349100. https://doi. org/10.1215/03616878-9349100

Tversky, A., \& Kahneman, D. (1973). Availability: A heuristic for judging frequency and probability. Cognitive psychology, 5(2), 207-232. https://doi.org/10.1016/ 0010-0285(73)90033-9

Tyson, A. (2020, July 22). Republicans remain far less likely than Democrats to view COVID-19 as a major threat to public health. Pew Research Center. https://www.pewresearch.org/ fact-tank/2020/07/22/republicans-remain-far-less-likely-than-democrats-to-viewcovid-19-as-a-major-threat-to-public-health/

Weinstein, N. D. (1980). Unrealistic optimism about future life events. Journal of Personality and Social Psychology, 39(5), 806-820. https://doi.org/10.1037/0022-3514.39.5.806

Weinstein, N. D. (1989). Effects of personal experience on self-protective behavior. Psychological Bulletin, 105(1), 31-50. https://doi.org/10.1037/0033-2909.105.1.31

Zaller, J. R. (1992). The nature and origins of mass opinion. Cambridge University Press. 